DOI: $10.21802 / \operatorname{artm} .2019 .4 .12 .158$.

УДК [616-08-059+615.825]:378.096

\title{
СУЧАСНІ АСПЕКТИ ВИВЧЕННЯ ТЕМИ “ОСНОВИ ФІЗИЧНОЇ РЕАБІЛІТАЦЇ” НА МЕДИЧНИХ ФАКУЛЬТЕТАХ ЗАКЛАДІВ ВИЩОЇ ОСВІТИ
}

\author{
Ю.Й. Рудий ${ }^{1}$ І І.К. Чурпій${ }^{2}$, О.В. Марчук ${ }^{1}$ I.В. Руда ${ }^{3}$, Л.Є. Атаманчук ${ }^{4}$ \\ ${ }^{1}$ Віннищький національний медичний університет ім. М. І. Пирогова, кафедра медичної реабілітації \\ та медико-сочіальної експертизи, м. Вінниця, Украӥна, \\ ORCID ID: 0000-0002-9910-4605, e-mail: yuriirudyi@gmail.com, \\ ORCID ID:0000-0002-8033-0653,e-mail:medredaktor@gmail.com \\ ${ }^{2}$ Івано-Франківський наиіональний медичний університет, кафедра фізичної реабілітаиії, \\ ерготерапії та фізичного виховання, м. Івано-Франківськ, Україна, \\ ORCID ID: 0000-0003-1735-9418, e-mail: ch.igor.if@gmail.com \\ ${ }^{3}$ Вінницький національний медичний університет ім. М. І. Пирогова, кафедра терапевтичної \\ стоматологї̈, м. Вінниця, Украӥна, \\ ORCID ID: 0000-0002-1994-7013, e-mail: ivruda2017@gmail.com \\ ${ }^{4}$ Науково-дослідний інститут реабілітаиії осіб з інвалідністю (навчально-науково-лікувальний \\ комплекс) Віннищького національного медичного університету ім. М.І. Пирогова, м. Вінниия, Украӥна, \\ ORCID ID: 0000-0001-6538-4189, e-mail: atamanczuklilia@gmail.com
}

Резюме. У статті викладені методичні особливості та теоретичні аспекти вивчення теми “Основи фізичної реабілітації” серед студентів-медиків.

Для більш чіткого розуміння та вивчення основних аспектів цієї теми запропоновано розглянути узагальнені дані сучасних україномовних підручників та посібників, якими студенти найчастіше користуються при підготовці до практичних занять. Також доцільно розглянути деякі аспекти вивчення цієї теми при самостійній підготовці студентів до практичних занять, зокрема й питання визначення та застосування рухових режимів в різні періоди фізичної реабілітації.

Багаторічний досвід застосування фізичних вправ показав їхню значимість в охороні здоров'я. Ефективність впливу фізичних вправ знаходиться в прямій залежності від обсягу та своєчасності їх призначення та визначається руховими режимами.

Режими рухової активності хворих розроблені для умов стаціонарного, санаторного та амбулаторнополіклінічного етапів реабілітації. Кожен з них чітко визначає об'єм і інтенсивність фізичного навантаження, яке повинен отримати хворий при кожному з них. Це дає можливість розробити алгоритм рухової активності людини в конкретний період захворювання, поставити завдання, визначити засоби для їх вирішення і обгрунтувати особливості методики ЛФК.

Представлені в статті матеріали значно розширять теоретичні уявлення та допоможуть студентам краще засвоїти цю тему. Сучасний підхід до питань визначення та застосування рухових режимів в різні періоди фізичної реабілітації забезпечує більш якісний рівень підготовки студентів до науково обгрунтованого проведення занять лікувальної фізкультури, праце- та механотерапії хворим на різних етапах реабілітації та відновного лікування.

Ключові слова: фізична реабілітація, рухові режими, періоди фізичної реабілітації, вища медична освіта

Вступ. У світлі реформування фізичної та реабілітаційної медицини України, післядипломної медичної освіти для студентів 4 курсу медичних факультетів закладів вищої освіти, які продовжують вивчати дисципліну «Фізична реабілітація та спортивна медицина», є дуже актуальною тема “Основи фізичної реабілітації”, що дозволяє раціонально та ефективно засвоїти спеціальні знання, уміння та навички оздоровчо-реабілітаційної роботи та сформувати теоретико-методичну основу для подальшого вивчення інших тем дисципліни «Фізична реабілітація та спортивна медицина».

Ця тема озброює студентів базовими знаннями про засоби фізичної реабілітації та методику їх застосування, а також формує уявлення про послідовність та безперервність реабілітаційного процесу на різних етапах відновного лікування хворих та людей з особливими потребами.

Вивчення теми "Основи фізичної реабілітації” проводиться у формі лекції, практичного заняття, самостійної та індивідуальної роботи студентів. Для успішного оволодіння знаннями 3 цієї теми велике значення мають самостійні заняття, які можна проводити у бібліотеці чи домашніх умовах, опрацьовуючи рекомендовану літературу або інформаційні ресурси Інтернету.

На сучасному етапі розвитку та модернізації вищої медичної освіти в Україні підхід до студента, 
який знаходиться у центрі процесу навчання, грунтується на повазі до його думки, на спонуканні до активності, на заохоченні до творчості. Основним завданням навчання студентів з медичної реабілітації $є$ формування навичок практичної діяльності, підготовки висококваліфікованого фахівця, який буде володіти необхідним об'ємом теоретичних знань, вміти застосовувати отримані знання на практиці [7 ].

У сучасних умовах в Україні склалася критична ситуація, пов'язана із станом здоров'я населення. В таких умовах фізична реабілітація посідає провідне місце, оскільки використовується як ефективний засіб комплексного відновлення фізичного здоров'я та працездатності хворих, осіб із ослабленим здоров'ям, спортсменів, людей з особливими потребами.

У статті пропонуємо розглянути деякі аспекти вивчення теми “Основи фізичної реабілітації” при самостійній підготовці студентів до практичних занять, зокрема й питань визначення та застосування рухових режимів в різні періоди фізичної реабілітації.

Результати дослідження та їх обговорення. У науковій і навчально-методичній літературі (педагогічного, психологічного, медичного та інших напрямів) наведено понад 60 формулювань поняття «реабілітація» (лат. rehabilitatio - відновлення), що свідчить про його багатоаспектність, дискусійність та відсутність уніфікованого загальноприйнятого трактування, яке б задовольнило усіх, хто займається питаннями реабілітації у широкому іiі розумінні $[10$, $11,12]$.

3 огляду на термінологічну розрізненість понять в сучасних публікаціях необхідно спочатку дати визначення основних термінів.

Медична реабілітація більшістю фахівцями розглядається як сукупність лікувальнодіагностичних і лікувально-профілактичних заходів, спрямованих на своєчасну і точну діагностику, госпіталізацію, а також відновлення і розвиток фізіологічних функцій хворого, виявлення його компенсаторних можливостей, усунення патологічного процесу, попередження ускладнень, відновлення або часткову компенсацію втрачених функцій, протидію інвалідності, підготовку тих, хто одужує, й інвалідів до побутових і трудових навантажень, активного самостійного життя [5, 13, 14 ].

Теоретичний аналіз наукових джерел дозволив розглянути фізичну реабілітацію як відновлення (або компенсацію) частково або повністю порушених (втрачених) функцій організму та працездатності хворих і інвалідів засобами лікувальної фізичної культури, масажу, фізіотерапії та природними чинниками. В. М. Мухін [10] зазначає, що фізична реабілітація є «невід’ємною складовою медичної реабілітації і застосовується в усіх її періодах і етапах».

Найбільш активним, цілеспрямованим і дієвим засобом фізичної реабілітації є лікувальна фізична культура (ЛФК) - метод відновного лікування, $[10,8,15,16]$, який не має рівноцінних аналогів за своїм природно-біологічним впливом, завдяки чому саме він відіграє головну роль серед інших немедикаментозних відновних та профілактичних заходів.
Лікувальна фізична культура - метод лікування, який використовує засоби фізичної культури для більш швидкого і повного відновлення здоров'я і працездатності хворого, а також для попередження (чи усунення) наслідків патологічного процесу (ранніх i/або пізніх ускладнень).

Слід зазначити, що у зарубіжних країнах, та й віднедавна в Україні, в контексті реабілітаційної діяльності застосовується термін «фізична терапія», що за сутністю та змістом $є$ фактично ідентичним терміну «фізична реабілітація».

Важливість розробки сучасної моделі періодизації реабілітаційного процесу з моменту початку захворювання до часткового або повного одужання давно є предметом дослідження багатьох фахівців. Однак диверсифікація варіантів, пропонованих авторами, настільки велика, що не дозволяє як фахівцям, так і тим, хто навчаються, зрозуміти або прийняти загальні підходи до розробки періодизації в ЛФК.

ЛФК займає провідне місце в процесі фізичної реабілітації. 3 моменту прояву клінічних симптомів до одужання проходить певний часовий інтервал, який умовно ділять на відповідні етапи (відрізок часу, ознаменований будь-якою якісною зміною) та періоди (стадія будь-якого процесу).

Найчастіше розрізняють три етапи реабілітації: стаціонарний, санаторний і поліклінічний, кожен 3 яких додатково поділяється на періоди 3 характерними руховими режимами. Ще більше різних варіантів назв періодів кожного етапу. Більшість фахівців сходяться на класифікації за назвою періодів стаціонарного етапу - щадний, функціональний і відновний / тренувальний. У всіх випадках руховий режим призначається з урахуванням захворювання і функціонального стану хворого. Останнє, своєю чергою, визначається періодом (фазою хвороби). Розрізняють періоди хвороби: гострих явищ, зворотного розвитку хвороби, залишкових явищ. Їм відповідають періоди призначення ЛФК: мобілізаційний, функціональний і реабілітаційний. На санаторному етапі часто зустрічаються такі назви: вступний, основний, заключний періоди. На поліклінічному етапі відзначений також своєрідний діапазон за кількістю періодів і їх назвою залежно від захворювань. Так, при хронічних захворюваннях, в ортопедії рекомендується виділяти адаптаційний, тренувально-коригувальний, стабілізаційний. У кардіології (в реабілітації постінфарктних хворих) запропоновано чотири періоди - перехідний, впрацювання, часткового обмеження, повної працездатності $[3,4,7]$.

Багаторічний досвід застосування фізичних вправ показав їхню значимість при лікуванні хворих. Лікувальна дія фізичних вправ різноманітна. Насамперед, зменшується негативний вплив зниженої рухової активності. Фізичні вправи підсилюють захисні реакції організму, прискорюють регенеративні процеси в хворих органах, формують оптимальні компенсаторні механізми, у багатьох хворих відновлюють порушені патологічним процесом функції. Ефективність впливу фізичних вправ знаходиться в прямій залежності від обсягу та своєчасності їх призначення та визначається руховими режимами. 
На сьогодні в системі фізичної реабілітації відсутня єдина класифікація рухових режимів, поняття, що вкладаються в них, широко варіюють, часом принципово відрізняються і навіть виключають один одного. Так, в травматології та хірургії вони визначені під назвою періодів, етапів або фаз лікування. Така ж картина спостерігається в неврології. У терапії при всіх захворюваннях орієнтуються на режими, розроблені для лікування хворих з інфарктом міокарда. У поліклініці після інфаркту міокарда Журавльова О.І., Граевская Н.Д. [3] виділяють наступні режими рухової активності: щадний, щадно-тренувальний, тренувальний та інтенсивно-тренувальний. При цьому автори для хворих із захворюваннями артерій (атеросклероз) рекомендують абсолютно незрозуміле об'єднання назв режимів: палатний, щадний, тренувальний.

У роботі В.А. Єпіфанова [16] вказується, що ступінь інтенсивності фізичних навантажень, їх обсяг повинні відповідати режиму рухової активності: щадний - режим малих, помірних за інтенсивністю навантажень; щадно-тренувальний - режим навантажень середньої інтенсивності; тренувальний - режим середніх і великих фізичних навантажень, близьких до рухових нормативів здорових нетренованих людей. Автор вводить рекомендації в кількісному вираженні: - при щадному режимі 3-4 години рухової активності протягом дня; - при щадно-тренувальному режимі - 4-5 годин; - при тренувальному - 5-6 годин. У межах зазначеного часу проводяться організовані або самостійні заняття ЛФК, а також застосовуються індивідуальні види рухової активності, в тому числі побутової, професійної.

У роботі [8] були розроблені рухові режими, які регламентують фізичне навантаження відповідно до патоморфологічних змін у хворому органі і забезпечують умови для патогенетичного функціонального лікування. Автори виділяють 4 рухових режими: щадний, тонізуючий, відновлювальний та тренувальний.

Колісник П.Ф. [9] вказує на використання у вертебрологічних пацієнтів 4 режимів лікувальної фізкультури: щадний, мобілізуючий, тренувальний та тракційно-тренувальний. При цьому автор не уточнює, на якому етапі медичної реабілітації застосовуються ці режими.

Змішування понять і надання однієї і тієї ж назви руховим режимам та періодам пов'язано з тим, що в основу покладено різні дефініції. В основу рухових режимів для стаціонарного етапу покладено загальний стан хворого, а для санаторного та поліклінічного етапів - це вже величина тренувальних навантажень. Такий стан можна пояснити відсутністю єдиного підходу до обгрунтування рухових режимів. Як правило, мова йде про емпіричний підхід до розширення рухової активності хворих. При цьому зміст режиму визначається набором форм ЛФК та їх тривалістю застосування. Природно, така ситуація не може не позначатися негативно на результатах лікування.

Враховуючи наведені дані, пропоную для більш чіткого розуміння та вивчення основних аспектів цієї теми розглянути узагальнені матеріали сучасних україномовних підручників та посібників, якими студенти найчастіше користуються при підготовці до практичних занять. Послідовність і методика застосування основних засобів фізичної реабілітації викладена відповідно до періодів та етапів медичної реабілітації, що пропонуються експертами ВОО3 [1, 10, $11,13,14,15]$.

У медичній реабілітації розрізняють два періоди: лікарняний та післялікарняний; у кожного 3 них $є$ визначені етапи. Перший період містить I етап реабілітації - лікарняний (стаціонарний), а післялікарняний період - II етап - поліклінічний, або реабілітаційний, санаторний і III етап - диспансерний (Мухін B.M., 2005).

Періодом в ЛФК називають часовий відрізок, який характеризує анатомо-функціональний стан пошкодженого органу та організму в цілому. Ефективне використання фізичних вправ з лікувальною метою вимагає продуманого плану їх проведення, який залежить від динаміки захворювання. Відповідно до основних закономірностей перебігу патології весь курс ЛФК умовно поділяють на три періоди.

Перший період - щадний - характеризується вираженими анатомічними і функціональними порушеннями ушкодженого органу, відповідної системи і організму взагалі, симптомами, притаманними цій хворобі чи травмі, вимушеним зниженням рухової активності, відповідає фазі мобілізації організмом механізмів боротьби з хворобою і формуванню тимчасових компенсацій; його основними завданнями є: стимуляція відновних процесів; попередження ускладнень, які зумовлені основним захворюванням; профілактика негативних явищ, пов'язаних з вимушеним обмеженням рухової активності: гіпостатичної пневмонії, тромбозу, тромбоемболії, гіпотонії кишечника (запорів), гіпотонії сечового міхура, м'язової слабкості та ін.; вибір адекватних навантажень.

Другий - функціональний - характеризується покращанням клінічного стану хворого, відновленням анатомічної цілісності органу чи тканин при одночасному суттєвому порушенні їх функції. Відповідає фазі зворотного розвитку патологічних змін і формуванню постійних компенсацій; до його основних завдань належать: ліквідація морфологічних змін; відновлення функції ураженого органу чи системи; формування постійних компенсацій; загальне та спеціальне тренування.

Третій - тренувальний - характеризується завершенням процесу одужання, відновлення функцій, але здатність витримувати життєві навантаження ще недостатня. Його завдання: ліквідація залишкових морфологічних і функціональних порушень; адаптація до побутових та трудових (виробничих) навантажень; підготовка до самостійних занять.

Залежно від профілю хворих зазначені періоди ЛФК мають певні назви. Зокрема, у пацієнтів терапевтичного профілю виділяють підготовчий, основний (відновний, одужання) та заключний (підтримуючий, тренувальний) періоди ЛФК. У травматології весь курс ЛФК умовно поділяють на: період іммобілізації (абсолютної та відносної), постіммобілізаційний та відновний. У хірургії розрізняють передопераційний, післяопераційний (ранній і пізній) та віддалений післяопераційний періоди. В неврології 
виділяють ранній відновний, пізній відновний та резидуальний (компенсації остаточних порушень) періоди.

Руховий режим є складовим елементом лікувального режиму, а ЛФК - частиною рухового режиму. У режимі рухової активності використовуються всі засоби, форми, методи і методичні принципи ЛФК, призначувані у відповідному дозуванні залежно від клінічного перебігу хвороби, стану функціональних можливостей і адаптаційної здатності організму хворого.

Для призначення ЛФК хворим різного профілю пропонуються уніфіковані режими рухової активності. Призначення нового режиму рухової активності здійснюється 3 появою адаптації хворого до фізичного навантаження попереднього режиму. Пасивний режим (гіподинамія) негативно позначається на одужанні. При цьому необхідно пам'ятати, що як спокій, так і рух $\epsilon$ нерозривними елементами режиму хворого, вони повинні не протиставлятися, а доповнювати один одного. Активний режим має стимулюючий і тренувальний вплив на весь організм, зміцнює волю хворого, впевненість у своїх силах, впливає на психічне здоров'я, розвиває функціональну адаптацію організму до тих фізичних навантажень.

Ефективність лікувально-відновного процесу залежить від раціональної побудови рухового режиму - раціональне використання та розподіл різних видів рухової активності хворого протягом дня в певній послідовності по відношенню до інших засобів комплексної терапії.

Призначення рухового режиму має на меті вирішити конкретні лікувальні завдання, що виникають в ході реабілітації. Руховий режим, по суті, визначає обсяг, кількість і характер диференційованих і недиференційованих рухів (локомоцій), які виконуються хворим в певній послідовності. Всі види фізичної активності пацієнта, які регламентуються в рамках рухового режиму, можна розділити на побутову (гігієна, прийом їжі, дозвілля та інше), реабілітаційну, що включає диференційоване застосування засобів ЛФК і трудотерапії, і маніпуляційну або процедурну активність, що вимагає від пацієнта виконання певних рухів, пов'язаних із діагностичними або лікувальними медичними процедурами. У стаціонарі руховий режим є невід'ємною частиною загального лікувально-охоронного режиму.

Принципи раціонально побудованого рухового режиму, що забезпечує ефективну медичну реабілітацію, такі: створення можливості постійної стимуляції процесів саногенезу (механізмів одужання) i стримування процесів патогенезу (механізмів розвитку хвороби) шляхом спрямованого впливу на організм і окремі його системи шляхом диференційованої рухової активності; повна адекватність фізичного навантаження нозологічній формі захворювання i характеру ii клінічного перебігу, функціональним можливостям організму пацієнта, віку хворого і попередньому руховому анамнезу; сприяння поступової адаптації організму хворого до зростаючого фізичного навантаження 3 метою досягнення рівня рухової активності, що відповідає віку; відновлення і закріплення оптимального динамічного стереотипу; підви- щення загальної фізичної працездатності, відновлення побутових і трудових навичок або формування нових.

Режими рухової активності хворих розроблені для умов стаціонарного, санаторного та амбулаторно-поліклінічного етапів реабілітації. Кожен 3 них чітко визначає об'єм і інтенсивність фізичного навантаження, яке повинен отримати хворий при кожному 3 них.

Режими рухової активності на стаціонарному етапі реабілітації. У стаціонарах призначають суворий ліжковий, розширений ліжковий, напівліжковий (палатний) та вільний (загальнолікарняний) режими.

Ліжковий режим призначається після оперативних втручань, при тяжкому загальному стані хворого, при захворюваннях, які можуть ускладнюватись при вставанні (перші дні після перенесеного інфаркту міокарда, порушеннях мозкового кровообігу тощо). Суворий ліжковий режим передбачає постійне перебування хворого у лежачому положенні та забезпечення йому повного фізичного та психічного спокою. Слід зазначити, що тривале перебування хворого на суворому ліжковому режимі та пов'язаний 3 цим вимушений дефіцит рухової активності значно подовжує процес одужання та призводить до виникнення серйозних ускладнень й функціональних порушень у більшості систем організму. Призначення ЛФК необхідне для стимуляції, насамперед, екстракардіальних чинників кровообігу, дихання, попередження ранніх ускладнень захворювання і гіподинамічного синдрому, створення відносного психофізичного спокою, підготовки хворого до активнішої фази режиму. Дозволені рухи для дистальних відділів кінцівок, статичні дихальні вправи в повільному темпі, 3 невеликим числом повторень. Тривалість заняття 510 хвилин. Напівповороти, їжа, гігієнічні процедури за сторонньою допомогою.

Розширений ліжковий режим призначають при позитивній динаміці клінічної симптоматики та показників додаткових методів обстеження. Він спрямований на прискорення розрішення патологічного процесу, попередження ускладнень, зумовлених тривалим перебуванням хворого у ліжку. Постійне перебування хворого в ліжку в положенні лежачи на спині, на спині з піднятим головним кінцем ліжка, на боці, на животі. При задовільному стані можливі активні повороти в ліжку (в спокійному темпі), короткочасне (2-3 рази на день по 5-12 хв.) перебування в ліжку в положенні сидячи, спочатку 3 опорою на подушки, оволодіння навичкою самообслуговування. Дозволені фізичні вправи з навантаженням на дрібні і середні м'язові групи і суглоби, виконувані в повільному темпі, з невеликим числом повторень кожного; дихальні вправи статичного і динамічного характеру, вправи на координацію рухів та тренування вестибулярного апарату. Задачами ЛФК є ліквідація ранніх і попередження пізніх ускладнень захворювання, помірна тонізація екстракардіальних чинників кровообігу, адаптація серцево-судинної системи до малих фізичних навантажень. Дозування індивідуальне, збільшується амплітуда рухів і кількість повторень вправ. 
Напівліжковий режим (палатний) характеризується задовільним загальним станом хворого на фоні знижених функцій життєво важливих систем організму. Відбувається поступова адаптація серцевосудинної системи і всього організму хворого до фізичного навантаження, попереджається розвиток пізніх ускладнень. Дозволені рухи для всіх м'язових груп 3 положення лежачи, сидячи, при задовільному стані стоячи, статичні й динамічні дихальні вправи, дозування навантаження індивідуальне. Загальна тривалість заняття 15-20 хвилин. Перехід у положення сидячи на ліжку з опущеними ногами або на стільці (2-4 рази на день по 10-30 хв.). При задовільному стані і при відсутності протипоказань хворому дозволяють пересуватися в межах палати 3 подальшим відпочинком в положенні сидячи і лежачи. Повне самообслуговування. Перебування в ліжку - 50\% денного часу. При палатному режимі хворому показана, ранкова гігієнічна гімнастка, лікувальна гімнастка, самостійні заняття.

Вільний режим (загальнолікарняний) призначається при задовільному загальному стані хворого, неповній ремісії захворювання. Головне завдання режиму - розширення рухової активності та сприяння розрішенню патологічного процесу. Адаптація до навантажень побутового i професійного характеру знижена. Основним завданням цього режиму є зближення клінічного видужання і функціонального відновлення організму, підготовка організму до виконання звичних трудових і побутових навантажень. У занятті застосовуються вправи спеціальної і загальної спрямованості, статичного і динамічного характеру в різних початкових положеннях, з повною амплітудою рухів, з предметами і приладами у залі та в лікувальному басейні (при показаннях). Загальна тривалість заняття - 20-35 хвилин, хворий майже весь денний час проводить сидячи, стоячи, в ходьбі. Рухова активність хворого в межах лікарні не обмежена.

Режими рухової активності у післялікарняному періоді реабілітації. За необхідності продовження реабілітації хворих після виписування із стаціонару, їх направляють на лікування в реабілітаційно-оздоровчий центр, санаторій чи поліклініку. Рухові режими на амбулаторно-поліклінічному, санаторно-курортному та диспансерному етапах реабілітації спрямовані на подальше відновлення стану здоров'я, підвищення функціональних можливостей, тренованості організму, адаптації до навантажень побутового і виробничого характеру. Залежно від рівня функціональних можливостей хворому можуть призначатися щадний, щадно-тренувальний та тренувальний рухові режими. Загальні завдання режимів: збільшення стійкості організму до навантажень, поступовий перехід хворого до повноцінного відновлення рухової актив- ності та фізичної працездатності, підготовка до трудової діяльності. Необхідно звернути увагу, що між усіма вказаними режимами існує сувора послідовність.

Щадний режим призначають усім хворим, як режим адаптації, протягом перших 3-5 днів. Особливістю цього режиму $є$ те, що хворі переходять із стаціонарного спостереження на поліклінічне чи санаторне. В перші дні після виписування із стаціонару хворі повинні зменшити об'єм рухової активності, обмеживши дистанцію ходьби, сходження на сходинки, кількість вправ у комплексі. Через 3-5 днів (за відсутності ускладнень) допускається повернення до обсягу навантажень, досягнутого при виписуванні 3 лікарні. Хворі з явищами декомпенсації, з недостатністю кровообігу та дихальною недостатністю I-II ступеня, ослаблені хворі, зі схильністю до загострень хронічних захворювань та ті, що потребують постійного лікарського контролю, повинні дотримуватись щадного рухового режиму протягом всього перебування на амбулаторному лікуванні чи в санаторії. Показані усі форми проведення ЛФК.

Щадно-тренувальний режим передбачає тонізуючий (помірний) вплив. Призначають хворим iз порушенням кровообігу та дихальною недостатністю І ступеня, усім хворим, старшим 60 років, у період ремісії основного захворювання та при задовільній адаптації до умов і засобів реабілітації. Режим забезпечує високу ефективність рухових, кліматичних, бальнео- та фізіотерапевтичних навантажень, сприяє підвищенню тонусу, тренованості та загартованості організму. Показані усі форми проведення лікувальної фізкультури.

Тренувальний режим призначають хворим без порушення кровообігу та дихання, зі стійкою компенсацією, задовільною адаптацією до кліматичних і фізичних навантажень. Режим спрямований на загартування, тренування організму, підготовку до трудової діяльності. Показані усі форми проведення ЛФК.

Слід зазначити, що виділяють також інтенсивно-тренувальний руховий режим, але в лікувальній фізичній культурі він практично не застосовується.

Представлені рухові режими є уніфікованими в ЛФК при різних захворюваннях. Це дає можливість розробити алгоритм рухової активності людини в конкретний період захворювання, поставити завдання, визначити засоби для їх вирішення і обгрунтувати особливості методики ЛФК. Для наочності та покращення засвоєння матеріалу представляю узагальнену схему Бісмак О.В. [1], яка демонструє взаємозв'язок етапів фізичної реабілітації, періодів застосування ЛФК та рухових режимів (рис. 1). 


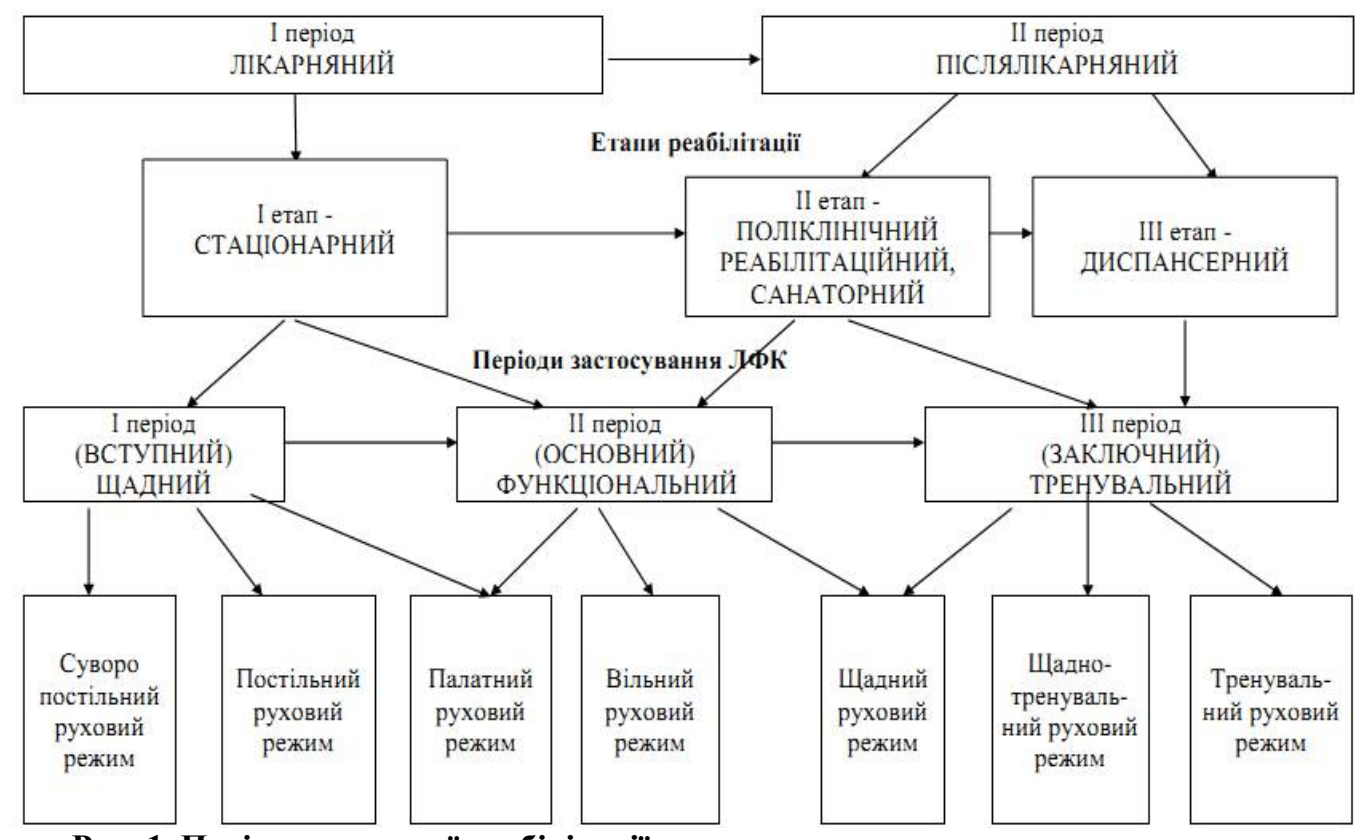

Рис. 1. Періоди медичної реабілітації.

Висновки та перспективи подальших розробок. На сучасному етапі розвитку та модернізації вищої медичної освіти в Україні основним завданням навчання студентів 3 фізичної реабілітації $є$ формування навичок практичної діяльності, підготовки висококваліфікованого фахівця, який буде володіти необхідним об'ємом теоретичних знань, вміти застосовувати отримані знання на практиці.

На основі отриманих знань 3 основ фізичної реабілітації підготувати студентів до науково обгрунтованого проведення занять лікувальної фізкультури, праце- та механотерапії хворим на різних етапах реабілітації та відновного лікування.

Впровадження в навчальний процес інформаційно-комунікативних технологій буде сприяти інтенсифікації процесу навчання та самостійної роботи студентів на кафедрі медичної реабілітації та медико-соціальної експертизи та підвищувати його ефективність.

Отже, якісна підготовка сучасних лікарів неможлива без досконалого оволодіння основами фізичної реабілітації. Недоццінка і недостатнє або несвоєчасне застосування засобів фізичної реабілітації в комплексному лікуванні хворих різного профілю часто призводить до суттєвого збільшення термінів їх одужання, виникнення важких ускладнень, і навіть до стійкої втрати працездатності. ЛФК й інші фізичні чинники повинні бути не додатковими засобами, а невід'ємною складовою комплексного лікування протягом усіх періодів та етапів реабілітації.

Досвід проведення занять зі студентами 4 курсу медичних факультетів на тему “Основи фізичної реабілітаціі” свідчить про те, що представлені в статті матеріали значно розширять теоретичні уявлення та допоможуть студентам краще засвоїти дану тему.

\section{References:}

1. Bismak OV, Melnik NG. Osnovi fizichnoyi reabilitaciyi (Fundamentals of physical rehabilitation). Harkiv: Brovin; 2010. (In Ukrainian).

2. Lyannoj YO. Viznachennya periodiv i etapiv reabilitaciyi u vikladanni disciplin profesijnoyi pidgotovki magistrantam $\mathrm{z}$ fizichnoyi reabilitaciyi (Determination of periods and stages of rehabilitation in teaching the disciplines of vocational training to undergraduate students in physical rehabilitation). Problems of Modern Pedagogical Education 2013; 39:262-70. (In Russian).

3. Zhuravleva AI. Sportivnaya medicina i lechebnaya fizkultura (Sports medicine and physical therapy). Moscow: Medicina; 1993. (In Russian).

4. Korshunov OI, Kuropatkina NA. Ocherki teorii i metodiki lechebnoj fizicheskoj kultury i kinezoreabilitacii (Essays on the theory and methodology of therapeutic physical training and kinesitherapy). Volgograd: 2015. (In Russian).

5. Popova SN. Fizicheskaya reabilitaciya (Physical rehabilitation). Moscow: Academiya; 2013. (In Russian).

6. Devyatova MV, Karlova NS. Obosnovanie unificirovannyh dvigatelnyh rezhimov v LFK (Substantiation of unified motor modes in PT). Saint Petersburg: S.-Peterb. gos. akad. fiz. kultury im. P.F. Lesgafta; 2002. (In Russian).

7. Lutkov VF. Sovremennye problemy organizacii etapov reabilitacii pri travmah oporno-dvigatelnogo apparata u sportsmenov neolimpijskih vidov sporta (Modern problems of organization of stages of rehabilitation at injuries of the musculoskeletal system in athletes of non-Olympic sports). Saint Petersburg: Izdatelstvo SPbGMU; 2015. (In Russian).

8. Smirnov GI. Posobie po lechebnoj fizkulture dlya samostoyatelnoj podgotovki studentov, zaochnogo obucheniya i studentov, obuchayushihsya po individualnomu grafiku (The manual on therapeutic physical education for independent preparation of students, correspond- 
ence training and students studying on an individual schedule). 6th ed. Saint Petersburg: 2008. (In Russian)

9. Kolisnyk PF. Lektsii z klinichnoi vertebrolohii (Lectures on clinical vertebrology). 1st ed. Vinnytsia: Nova Knyha; 2016. (In Ukrainian).

10. Muchin VM. Fizychna reabilitacia [Physical rehabilitation]. Kyiv: Olimpiyska literatura; 2009. P.488. (In Ukrainian).

11. Marchenko OK. Osnovy fizicheskoj reabilitacii [The basics of physical rehabilitation]. Kyiv: Olimp; 2012. P.528. (In Russian).

12. Ponomarenko GN. Fizicheskaya i reabilitacionnaya medicina [Physical and rehabilitation medicine]. Moscow: Geotar-Media; 2016. P.688.In Russian].

13. Yushkovskaya OG, Kuhar NN, Plakida AL. Fizicheskaya reabilitaciya [Physical rehabilitation]. Odessa: Poligraf; 2016. P.160. (In Russian).

14. Abramov VV, Klapchuk VV, Nehanevich OB. Fizichna reabilitaciya, sportivna medicina [Physical therapy, sports medicine]. Dnipro: Zhurfond; 2014. P.456. (In Ukrainian).

15. Sokolovskij VS, Romanova NO, Yushkovska OG. Likuvalna fizichna kultura [Therapeutic physical culture]. Odessa: Odessa medical university; 2005. P.234. (In Ukrainian).

16. Epifanov VA. Lechebnaya fizicheskaya kultura [Therapeutic physical culture]. Moscow: Medicina; 2017. (In Russian).

\section{УДК [616-08-059+615.825]:378.096}

\section{СОВРЕМЕННЫЕ АСПЕКТЫ ИЗУЧЕНИЯ ТЕМЫ "ОСНОВЫ ФИЗИЧЕСКОЙ РЕАБИЛИ- ТАЦИИ" НА МЕДИЦИНСКИХ ФАКУЛЬТЕТАХ УЧРЕЖДЕНИЙ ВЫСШЕГО ОБРАЗОВАНИЯ}

\author{
Ю.И. Рудой ${ }^{1}$, И.К. Чурпий ${ }^{2}$, А.В. Марчук ${ }^{1}$, \\ И.В. Рудая ${ }^{3}$, Л.Е. Атаманчук ${ }^{4}$
}

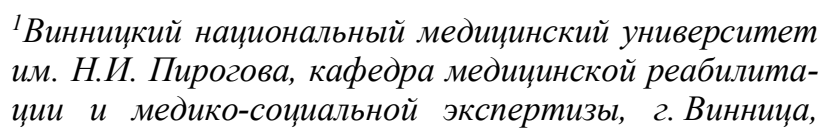

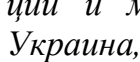

ORCID ID: 0000-0002-9910-4605,

e-mail:yuriirudyi@gmail.com,

ORCID ID: 0000-0002-8033-0653,

e-mail:medredaktor@gmail.com

${ }^{2}$ Ивано-Франковский национальный медицинский университет, кафедра физической реабилитаџии, эрготерапии и физического воспитания,

2. Ивано-Франковск, Украина,

ORCID ID: 0000-0003-1735-9418,

e-mail: ch.igor.if@gmail.com

${ }^{3}$ Винниикий национальный медицинский университет им. Н.И. Пирогова, кафедра терапевтической стоматологии, г. Винница, Украина,

ORCID ID: 0000-0002-1994-7013,

e-mail: ivruda2017@gmail.com

${ }^{4}$ Научно-исследовательский институт реабилитации лии с инвалидностью (учебно-научно-лечебньй комплекс) Винницкого нациионального медицинского уни- верситета им. М.И. Пирогова, г. Винница, Украина, ORCID ID: 0000-0001-6538-4189,

e-mail: atamanczuklilia@gmail.com

Резюме. В статье изложены методические особенности и теоретические аспекты изучения темы "Основы физической реабилитации" среди студентовмедиков.

Для более четкого понимания и изучения основных аспектов этой темы предложено рассмотреть обобщенные данные современных украиноязычных учебников и пособий, которые студенты чаще всего используют при подготовке к практическим занятиям. Также целесообразно рассмотреть некоторые аспекты изучения этой темы при самостоятельной подготовке студентов к практическим занятиям, которые касаются вопросов определения и применения двигательных режимов в разные периоды физической реабилитации.

Эффективность воздействия физических упражнений находится в прямой зависимости от объема и своевременности их назначения и определяется двигательными режимами.

Режимы двигательной активности больных разработаны для условий стационарного, санаторного и амбулаторно-поликлинического этапов реабилитации. Каждый из них четко определяет объем и интенсивность физической нагрузки, которую должен получить больной при каждом из них. Это дает возможность разработать алгоритм двигательной активности человека в конкретный период заболевания, поставить задачу, определить средства для решения и обосновать особенности методики ЛФК.

Представленные в статье материалы значительно расширят теоретические представления и помогут студентам лучше усвоить данную тему. Современный подход к вопросам определения и применения двигательных режимов в разные периоды физической реабилитации обеспечивает более качественный уровень подготовки студентов к научно обоснованному проведению занятий лечебной физкультуры, трудо- и механотерапии больным на различных этапах реабилитации и восстановительного лечения.

Ключевые слова: физическая реабилитация, двигательные режимы, периоды физической реабилитации, высшее медицинское образование.

\section{UDC [616-08-059+615.825]:378.096 \\ MODERN ASPECTS OF THE TOPIC "PHYSICAL REHABILITATION" STUDYING AT MEDICAL FACULTIES OF HIGHER EDUCATIONAL INSTITUTIONS}

Yu.Y. Rudyi ${ }^{1}$, I. K. Churpiy' ${ }^{2}$, O. V. Marchuk ${ }^{1}$, I. V. Ruda ${ }^{3}$, L. Ye.Atamanchuk ${ }^{4}$

${ }^{I}$ National Pirogov Memorial Medical University, Department of Medical Rehabilitation and Medical and Social Expertise, Vinnitsa, Ukraine,

ORCID ID: 0000-0002-9910-4605, 
e-mail: yuriirudyi@gmail.com,

ORCID ID: 0000-0002-8033 -0653,

e-mail:medredaktor@gmail.com

2Ivano-Frankivsk National Medical University,

Department of Physical Rehabilitation, Ergotherapy and

Physical Education, Ivano-Frankivsk, Ukraine,

ORCID ID: 0000-0003-1735-9418,

e-mail: ch.igor.if@gmail.com

${ }^{1}$ National Pirogov Memorial Medical University, Department of Therapeutic Dentistry, Vinnitsa, Ukraine, ORCID ID: 0000-0002-1994-7013,

e-mail:ivruda2017@gmail.com

4 Research Institute of theRehabilitation of Persons with Disabilities (educational-scientific-medical complex) of National Pirogov Memorial Medical University,

Vinnytsya, Ukraine,

ORCID ID: 0000-0001-6538-4189,

e-mail: atamanczuklilia@gmail.com

Abstract. Methodological features and theoretical aspects of the theme "Basics of physical rehabilitation" studying by medical students are presented in the article.

A review of the general data from modern Ukrainian textbooks, which are commonly used during the preparation to the study, where suggested for the more accurate understanding and learning of the main aspects of this theme. It is also relevant to review some aspects of this theme preparation, which are connected with the determination and use of movement regimes at different periods of physical rehabilitation, during the individual student's work before the practical lessons.

Sequence and methodology of use of the main tools of physical rehabilitation is presented according to the periods and stages of medical rehabilitation, which is suggested by WHO experts.

More than 60 definitions of the term "rehabilitation" is present in scientific and educational literature (pedagogical, psychological, medical and other directions). That indicate its versatility, disputability and absence of the unified generally accepted definition, which will satisfy all those, who participate in rehabilitation.

Medical rehabilitation is considered by the most of specialists as a complex of diagnostic, treatment and preven- tive measures, which are directed towards timely and accurate diagnosis, hospitalization, and also restoring and development of physiological functions of the patient, detection of compensatory capacities, elimination of the pathological process, prevention of complications, restoring or partly compensation of the lost function, resistance to disability, preparation of convalescents to domestic work and labor, active independent life.

It should be mentioned, that the term "physical therapy" is used in foreign countries, and recently in Ukraine, in the context of rehabilitation help with the purpose of stimulation and restoring of the movement activity, which by its sense is in fact identical to the term "physical rehabilitation".

A huge experience if physical exercise use have showed its significance in the healthcare. Efficacy of physical exercise correlate directly with the time of their administration and are determined by movement regimens.

Regimens of the movement activity were created for the condition of in-patient, outpatient and sanatorium stages of rehabilitation. Each of the, determines the volume and intensity of physical load, which patient should receive at each stage.

Movement regimens are unified in physical therapy in different disease. This provides a possibility to develop an algorithm of patient's movement activity at some stage of the disease, set tasks, and determine ways of their solving and justifying peculiarities of physical therapy methods.

Therefore, materials presented in the article will significantly broaden theoretical knowledge and will help students to understand this theme better.

Modern approach to the question of determining and use of movement regimens at different stages of physical rehabilitation provides for the qualitative level of student's preparation to evidence-based studies of physical therapy, labor and mechanic therapy in patients at different rehabilitation and restoring treatment.

Keywords: physical rehabilitation, regimens of the movement, periods of physical rehabilitation, higher medical education.

Стаття надійшла в редакцію 30.11.2019 р. 